\title{
Higher Education Expansion and Return to Education in China: Evidence from CGSS2005 and CGSS2013
}

\author{
Xinxin $\mathrm{Ma}^{1}$ \& Chengcheng Zhang ${ }^{2}$ \\ ${ }^{1}$ Institute of Economic Research, Hitotsubashi University, Japan \\ ${ }^{2}$ Graduate School of Economic, Hitotsubashi University, Japan \\ Correspondence: Xinxin Ma, Institute of Economic Research, Hitotsubashi University, Japan.
}

Received: May 23, 2017

Accepted: June 11, 2017

Online Published: June 22, 2017

doi:10.5430/ijfr.v8n3p85

URL: https://doi.org/10.5430/ijfr.v8n3p85

\begin{abstract}
We conducted an empirical study to estimate the private internal rate of return to years of schooling (IRR) in China during the period after the implementation of higher education expansion policy using data from the Chinese General Social Survey data conducted in 2006 and 2014 (CGSS2005, CGSS2013). The major conclusions are as follows: first, from 2005 to 2013 , IRR decreased from $8.6 \%$ to $7.8 \%$ for the whole sample, IRR decreased from $8.3 \%$ to $7.4 \%$ for men, and IRR decreased from $9.0 \%$ to $8.2 \%$ for women. Second, IRR values among various education category groups are different. IRR is greater for the high-level education group than that for the middle and low-level education groups in both 2005 and 2013. Third, to consider the impact of the higher education expansion policy on IRR, the IRR of the university graduates decreased from $15.4 \%$ (2005) to $11.2 \%$ (2013), whereas the IRR of the graduate school graduates rose from $10.1 \%$ (2005) to $19.0 \%$ (2013). The effect of the policy on IRR differs between the university and graduate school graduates. Fourth, the IRR is higher for women than for men. There is a gender disparity for IRR; IRR is different by ownership types, registration system types, industrial and regional groups in both 2005 and 2013.
\end{abstract}

Keywords: return to schooling, IRR, wage, higher education expansion policy

\section{Introduction}

Since 1978 the government has reformed the economic system in China. The government has changed the economic system from a planned economy to a market economy. For example, since the 1990s, the Chinese government has enforced state-owned enterprise (SOEs) reform, implemented foreign-investment policy, and China participated in the WTO in 2001. The registration system ("Hukou”) has been deregulated and migration from the rural regions to the urban regions has been permitted. It is expected that with the transformation of the economic system, the impact of market mechanisms on wage determination will become greater. In addition, the growth of the Chinese economy has grown massively since the 1990s. The average annual growth of GDP is around 10\% from 1990 to 2015 (NBS, 2016). It is thought that with economic growth, the labor demand for high-level skilled workers may increase, which may cause the wage level of the high-level education worker to rise. Therefore the influence of educational level on wages might become greater during the economic transition period (Note 1) (labor demand increase factor).

When considering the labor supply of high-level education workers, it should be noted that the Chinese government implemented a higher education expansion policy in 1999 (Li, et al., 2008; He, 2009; Wang and Liu, 2011; Xing and Li, 2011; Zhang and Chen, 2011; Chang and Xiang, 2013; and Gao and Smyth, 2015). The reasons for the government to promote this policy may be as follows: first, along with Chinese economic growth, the labor demand for high-level skilled workers increased. The higher education expansion policy was necessary in order to increase the labor supply of high-level education workers. Second, it addresses the youth unemployment problem. Notably, the government promoted ownership reform of SOEs in the late of 1990s. The number of workers laid-off increased with the progress of SOEs reform, which caused the rise in the unemployment rate since the 1990s (Note 2) (Ma, 2011). To address the youth unemployment problem, the government promoted admission to college or university. Third, the policy is expected to increase household education expenditure and facilitate other industrial development (e.g. construction industry, education service industry). After the higher education expansion policy was implemented, the number of university graduates increased dramatically from 1080 thousand in 1998 to 6,381 thousand in 2013 (NBS, 2016). When labor demand is consistent, it is thought that the increase of the high-level 
education labor supply may cause a wage decrease for the high-level education worker group (labor supply increase factor).

Based on the market equilibrium model, labor demand increase may cause wages to rise (labor demand increase factor); whereas higher education expansion policy may cause a labor supply increase, which may cause wage decrease (labor supply increase factor). Thus it is not clear how the influence of education on wages changed after the policy implementation. An important research issue is the estimation of the return to education during the period after the policy implementation because this enables evaluation of the impact of labor market reform and policy implementation on wages.

Although previous studies estimated the return to education in China, there remain some issues which should be considered. Using two wave survey data, Chinese General Social Survey (CGSS) data conducted in 2006 and 2014 (CGSS2005, CGSS2013), an empirical study is used to estimate the magnitude of the return to education and discuss the impact of higher education expansion policy on wages. The gender disparity of the return to education is discussed. We also make robustness checks to analyze the return to education by various groups: the public sector and private sector groups, regional groups, and the rural and urban registration groups.

This study is structured as follows: section 2 introduces the ways in which education influences wages, and empirical studies on the return to education in China. Section 3 gives the framework of the empirical analysis, including models and datasets. Section 4 presents estimated results and compares these results with the published studies, Section 5 summarizes the conclusions.

\section{Literature Review}

\subsection{The Channels of the Influence of Education on Wage}

How can education influence an individual wage? Two channels of influence can explain it. First, based on human capital theory (Becker, 1964; and Mincer, 1974), the individual wage is determined by individual labor productivity. Educational attainment is thought to be a part of human capital. High-level education expresses high labor productivity, which causes a high individual wage (schooling model). Second, based on the signaling model (or screening model), the "halo effect" of educational attainment (such as graduation from university or graduate school) signals a worker's potential quality to employers. From this viewpoint, the positive effect of education on wages is not because of the worker's high labor productivity, it just certifies that the worker may have an ability to do high-level skilled work in the future. Educational attainment can play a signaling role when it is difficult for employers to estimate the worker's potential ability.

However, some factors may affect the influence of education on wages. For example, the implementation by firms of a set of human resource management systems to improve the workers' motivation based on the internal labor market and efficient wage hypothesis. Another factor is that in China the wage determination system is different for the public sector (e.g. the government organization, state-owned enterprises) and the private sector (e.g. private-owned firm, foreign-investment firm). For example, in the public sector, the government controls the basic wage; whereas in the private sector, the wage level is decided by the market-mechanism. Thus the effect of educational level on wages might be different in these two sectors. Based on the discrimination hypothesis (Becker, 1957), even though the productivity of group A (e.g. women, rural resident workers) is similar to group B (e.g. men, urban resident workers), because there is discrimination for group A, which may come from employers, customers, counterpart colleagues or others, the wage level is set lower for group A than that for group B. Therefore the influence of educational level on wages may differ between various groups (women vs. men, urban resident workers vs. urban resident workers).

\subsection{Previous Empirical Studies on IRR in China}

Wage function is estimated based on Mincer (1974). The coefficient of schooling year in Mincer's wage function expresses the return to education, the value is approximate to the private internal rate of return to years of schooling (which is abbreviated as "IRR"). The main findings are as follows: OLS (Ordinary Least Square) is usually used in previous studies (Byron and Manaloto, 1990; Liu, 1998; Johnson and Chow, 1997; Liu, 1998; Lai, 1998; Li, 2003; Li and Ding, 2003; Bishop and Chiou, 2004; Heckman and Li, 2004; Zhang, et al. 2005; Qian and Smyth, 2008; Liu, 2008; Chen and Hamori, 2009; Qiu and Hudson, 2010; Ma, 2011; Ge and Yang, 2011; Kang and Peng, 2012; Ren and Miller, 2012; Deng and Ding, 2013; Wang, 2013; and Mishra and Smyth, 2014). In addition, in order to address the heterogeneity problem, IV (Instrument Variable) method is also utilized (Fleisher et al., 2004; Heckman and Li, 2004; Giles, et al., 2008; Chen and Hamori, 2009; Kang and Peng, 2012; Fang et al., 2012; Mishra and Smyth, 2013; Wang, 2012a, 2013; and Gao and Smyth, 2015). The estimated results in these studies are different in the periods analyzed and in data and methods. It is observed that the estimated IRR values range from 1.4 (Byron and Manaloto, 
1990) to 44.0 (Wang, 2012a) from 1988-2011 (see Appendix 1) (Note 3).

Although these studies have estimated IRR for China, the following issues should be explored thoroughly. First, the analysis periods in the published studies are limited to mainly before 2010, and recent information for the issue is scarce. Second, empirical study on the impact of the higher education expansion policy on IRR is scarce. Third, even though it is thought that the returns to years of schooling differ by educational category, the estimations of IRR by the various education categories are scarce. Fourth, although most empirical studies use male and female workers groups and compared the results of IRR, it is not clear if the other factors (e.g. experience year, occupation, industrial sector) are consistent, whether IRR differs by gender. Lastly, to consider if the labor supply and demand might differ for urban residents and rural residents, industrial sector and region sector groups, there may exist wage gaps between these groups (Note 4), and the IRR may differ for these groups. Moreover, because the wage determinate systems differ by public sector and private sector, the effect of education on wages may be different for these two sectors (Note 5). However, the studies which estimate IRR for these groups are insufficient.

The contributions of this study are as follows. First, we analyze the changes in return to education from 2005 to 2013, using the latest survey data (CGSS2013) which provides new evidence. 2005 to 2013 is relevant as it is the period following the implementation of the higher education expansion policy. We also discuss the impact of the policy on IRR. Second, IRR is calculated by various education category groups. As 2005 to 2013 is the period following the implementation of the higher education expansion policy, to compare the change of IRR for high-level education graduates, we discuss the impact of the higher education expansion policy on wages. Third, the gender disparity of IRR is estimated to control the other factors (e.g. individual characteristics, employment status, occupation, industry, regions) in order to investigate the differentials of IRR by gender. Lastly, IRR is estimated by other groups: public sector and private sectors, industrial sectors (primary, secondary and tertiary industries) and regional groups (Eastern, Central, and Western Regions).

\section{Methodology}

\subsection{Models}

First, to calculate IRR, this study uses the wage function based on OLS which is usually used in the previous studies (Note 6). It is expressed in equation (1).

$$
\ln \text { wage }_{i}=a+b_{e y} \text { eduyear }_{i}+b_{\exp } \exp _{i}+b_{\exp 2} \exp _{i}^{2}+b_{x} X_{i}+\varepsilon_{i}
$$

In equation (1), $\ln$ wage is the dependent variable (logarithmic value of wage); $i$ denotes individuals; eduyear is schooling years; exp denotes experience years; $X$ are the other factors which affect the individual wage (e.g. gender, occupations, employment status, industry sectors, and regions); $a$ indicates constant; and $\varepsilon$ is error item. The symbols $b_{1}, b_{2}, b_{3}, b_{x}$ are estimated coefficients. Here, $b_{1}$ indicates the estimated IRR (Mincer, 1974).

Then, to estimate IRR by various education category groups, the Psacharopoulos (1981) model is utilized. The model is expressed in equation (2) and (3).

$$
\begin{gathered}
\ln \text { wage }_{i}=a+b \cdot \text { level } 2+c \cdot \text { level } 3+d \cdot \text { level } 4+e \cdot \text { level } 5+f \cdot \text { level } 6+g \cdot \text { level }_{7} \\
+b_{\exp } \exp _{i}+b_{\exp 2} \exp _{i}+b_{x} X_{i}+\varepsilon_{i}
\end{gathered}
$$

In equation (2), level 2 level7 indicates the different education levels. In the study, they are a set of education dummy variables (no schooling, primary school, junior high school, senior high school, college and vocational school, university, and graduate school). $X$ is similar with that in equation (1). $b$ is estimated coefficients. Based on the set of coefficient of $b \sim g$, the IRR by education category groups can be calculated by equation (3): 
IRR of primary school: $\quad r_{\text {primayss }}=\frac{b}{6}$

IRR of junior high school: $\quad r_{\text {junionsprimay }}=\frac{c-b}{3}$

IRR of senior high school: $\quad r_{\text {seniors sunior }}=\frac{d-c}{3}$

IRR of college:

$r_{\text {collegevssenior }}=\frac{e-d}{3}$

IRR of university:

$r_{\text {universityssenior }}=\frac{f-d}{4}$

IRR of graduate school:

$$
r_{\text {graduats suniversity }}=\frac{g-f}{3}
$$

Lastly, to investigate the gender disparity of IRR, two kinds of methods are used. First, to consider the individual characteristics disparity by gender, subsamples female workers and male workers are used separately. This method is usually used in the published studies (Li and Ding, 2003; Zhang, et al., 2005; and Ma, 2011). However, the results from this method cannot investigate if, when the other factors (e.g., the occupation, industry sector or employment status) are consistent, the IRR differs by gender. To address the problem, the second model is used: it is expressed in equation (4).

$$
\ln \text { wage }_{i}=a+b_{\text {ey }} \text { eduyear }_{i}+b_{G} G_{i}+b_{G e} G \cdot \text { eduyear }_{i}+b_{\exp } \exp _{i}+b_{\exp 2} \exp _{i}^{2}+b_{x} X_{i}+\varepsilon_{i}
$$

In equation (4), $G$ indicates the gender dummy variable (equal to 1 if male, equal to 0 if female), $G \cdot$ eduyear

expresses the interaction item of $G$ and eduyear. $b$ is estimated coefficients. When $b_{G e}$ is statistically significant, it indicates that even though the individual characteristics are similar, IRR differs by gender. When $b_{G e}$ is negative statistically significant, it indicates that IRR is greater for women than that for men.

We also use a set of subsamples to estimate the IRR and compare the disparities of IRR among these groups: i. public sector (government organization, state-owned enterprises) and private sector groups; ii. Eastern, Central, and Western Region groups; and iii. the rural resident and urban resident groups.

\subsection{Data}

This study employs two periods of the Chinese General Social Survey (CGSS) survey data. The CGSS launched in 2003, which is the earliest national representative continuous survey project mainly conducted by Renmin University of China on mainland China. The CGSS is aimed to systematically monitor the changing relationship between social structure and the quality of life in both urban and rural China. The CGSS2003-2006 and CGSS2010-2013 use China's fifth census of 2000 and the 2010 national population censors data as a sampling frame with a multi-stage stratified design (Note 7). Although a CGSS has been conducted each year since 2003, to consider the impact of higher education expansion policy performed since 1999 on IRR, we select CGSS2005 and CGSS2013. CGSS2005 
was conducted in 2006 and the information for wages and jobs for 2005 which is the prior period of new workers graduated from the college, university or graduate school of university after the policy implementations; because CGSS2013 is the most recent survey, it will give us the most up to date information about the issue. The samples are composed of 10,372 (CGSS2005), and 11,438 (CGSS2013) individuals in 26 provinces and municipal cities, which covers nearly the whole of China. The CGSS includes respective information about individual characteristics (e.g., education, experience year, gender, and marital status), job information (e.g., employment status, wage, occupation, industry, and work place).

The self-employed, retired workers, and the unemployed are excluded because the subject of the study is employees. A retirement system and employee basic pension system have been implemented in the state-owned sector in China (Note 8). To reduce the effect of these systems on the analysis result, only those between the ages of 16 and 60 are included.

The dependent variable for the wage function is the logarithm of the annual wage (Note 9). The wage is defined as the total earnings from work (called "the total wage"). We use the CPI (consumption price index) in 2005 and 2013 to adjust the nominal wage. The explaining variables are the variables likely to affect the wage, such as years of schooling or education category dummy variables (no schooling, primary school, junior high school, senior high school/vocational school, college, university, and graduate school) (Note 10), experience years (Note 11), male dummy variable (equal to 1 if male, equal to 0 if female), communist party member (equal to 1 if communist party member, equal to 0 if not), regular worker dummy variable (equal to 1 if regular worker, equal to 0 if not), the married dummy variable (equal to 1 if married, equal to 0 if not), Han dummy variable (equal to 1 if Han majority, equal to 0 if minority), ownership (government organization, state-owned enterprises, private enterprises) dummy variables (Note 12), occupation (manager, technician, clerk, manual worker, the other) dummy variables, industry (primary, secondary and service and tertiary industries) dummy variables, rural registration dummy variable (equal to 1 if a worker with rural registration, equal to 0 if a worker with urban registration), and region (Western, Central, and Eastern Region) dummy variables.

The statistical description of variables is shown in Table 1. Years of schooling increased from 11.582 (2005) to 12.450 (2013): the proportion of college graduated worker increased from $16.8 \%$ (2005) to $20.9 \%$ (2013), the proportion of graduate school graduated worker increased from $8.9 \%$ (2005) to $20.2 \%$ (2013). It is shown that along with the implementation of the higher education expansion policy, the proportion of high-level education workers increased from 2005 to 2013. It is thought that the changes of labor supply of high-level education might affect the IRR from 2005 to 2013.

Table 1. Statistics description

\begin{tabular}{lcccc}
\hline & \multicolumn{2}{c}{2005} & \multicolumn{2}{c}{2013} \\
\cline { 2 - 5 } & Mean & S.D. & Mean & S.D. \\
\hline Wage yearly(Yuan) & 15448 & 14202 & 42344 & 48580 \\
Schooling years(year) & 11.582 & 3.049 & 12.450 & 3.343 \\
Experience years(year) & 16.845 & 10.183 & 15.190 & 10.509 \\
male & 0.572 & 0.495 & 0.598 & 0.490 \\
Communist party & 0.147 & 0.355 & 0.182 & 0.386 \\
member & 0.818 & 0.386 & 0.974 & 0.160 \\
Regular worker & 0.808 & 0.394 & 0.791 & 0.407 \\
The married & & & & \\
Regions & 0.164 & 0.370 & 0.126 & 0.332 \\
$\quad$ West & 0.580 & 0.494 & 0.641 & 0.480 \\
$\quad$ East & 0.256 & 0.437 & 0.233 & 0.423 \\
$\quad$ Central & & & & \\
Industry sectors & 0.013 & 0.115 & 0.004 & 0.064 \\
$\quad$ Primary industry & 0.354 & 0.478 & 0.350 & 0.477 \\
Secondary industry & 0.562 & 0.496 & 0.605 & 0.489 \\
$\quad$ Tertiary industry & & & &
\end{tabular}




\begin{tabular}{lllll}
$\begin{array}{l}\text { The other } \\
\text { Occupations }\end{array}$ & 0.071 & 0.257 & 0.041 & 0.200 \\
$\quad$ Manager & 0.023 & 0.148 & 0.107 & 0.309 \\
Technician & 0.188 & 0.391 & 0.280 & 0.449 \\
Clerk & 0.382 & 0.486 & 0.143 & 0.350 \\
Manual worker & 0.402 & 0.490 & 0.462 & 0.499 \\
$\quad$ The other & 0.005 & 0.078 & 0.008 & 0.095 \\
Ownership Category & & & & \\
Private sector & 0.492 & 0.500 & 0.590 & 0.492 \\
Government & 0.050 & 0.217 & 0.062 & 0.241 \\
SOE & 0.458 & 0.498 & 0.348 & 0.477 \\
Rural registration & 0.131 & 0.337 & 0.351 & 0.478 \\
Han & 0.953 & 0.213 & 0.947 & 0.224 \\
Education category & & & & \\
No schooling & 0.016 & 0.105 & 0.027 & 0.089 \\
& & & & \\
Primary school & 0.063 & 0.243 & 0.060 & 0.237 \\
Junior high school & 0.268 & 0.443 & 0.223 & 0.416 \\
Senior high school & 0.396 & 0.489 & 0.279 & 0.449 \\
College & 0.168 & 0.374 & 0.209 & 0.407 \\
University & 0.089 & 0.285 & 0.202 & 0.402 \\
\hline observations & 2,618 & & 2,403 & \\
\hline
\end{tabular}

Date source: Calculated based on CGSS2005 and CGSS2013.

Table 2 summarizes the mean value of annual wage and wage gaps between the various education category groups. For wage gaps between various educational category groups, the reference group is the wage mean value of senior high school (the middle-level education group). The main findings are shown below.

First, compared with workers graduated from senior high school, the wages are lower for no-schooling workers, and workers graduated from primary school and junior school (the low-level education group). Wages are higher for workers graduated from college, university, and the graduate school of university (the high-level education group) for both male and female workers in both 2005 and 2013. The results show a wage gap between various education al category groups in both 2005 and 2013.

Second, the wage gap between the various educational category groups differs by gender. For example, the wage gap between the middle-level education group (senior high school) and low-level education group (no schooling, primary school, junior high school, and senior high school) is greater for women than for men in both 2005 and 2013 . The education wage gap between the middle-level education group and high-level education groups (college, university, and graduate school of university) is overall greater for men than that for women in both 2005 and 2013.

Lastly, the wage gap changes from 2005 to 2013 differ by gender. For example, for the female group, the wage gap between senior high school and university decreased (from 2.36 in 2005 to 1.16 in 2013), whereas the wage gap between senior high school and the graduate school of university increased (from 2.75 in 2005 to 3.11 in 2013). However, for the male group, the wage gap between senior high school and university increased (from 1.57 in 2005 to 1.63 in 2013), whereas the wage gap between senior high school and the graduate school of university decreased (from 3.55 in 2005 to 3.21 in 2013). These results may be caused by the labor supply and demand for high-level education workers differing by gender. 
Table 2. Mean values of wage and wage gaps between various education category groups

\begin{tabular}{|c|c|c|c|c|}
\hline & & & \multicolumn{2}{|c|}{ Unit: Annual wage (Yuan) } \\
\hline & Male & Female & Gaps(1): Male & Gaps(2): Female \\
\hline \multicolumn{5}{|l|}{2005} \\
\hline Total & 16424 & 14145 & 1.05 & 1.10 \\
\hline \multicolumn{5}{|l|}{$\begin{array}{l}\text { Education } \\
\text { Categories }\end{array}$} \\
\hline a. No schooling & 8012 & 5579 & 0.51 & 0.43 \\
\hline b. Primary school & 10056 & 7648 & 0.64 & 0.60 \\
\hline c. Junior high school & 12338 & 9774 & 0.79 & 0.76 \\
\hline d. Senior high school & 15691 & 12845 & 1.00 & 1.00 \\
\hline d. College & 22155 & 17304 & 1.41 & 1.35 \\
\hline f. University & 24653 & 30354 & 1.57 & 2.36 \\
\hline g. Graduate school & 55673 & 35333 & 3.55 & 2.75 \\
\hline \multicolumn{5}{|l|}{2013} \\
\hline Total & 37703 & 26735 & 1.16 & 1.10 \\
\hline \multicolumn{5}{|l|}{$\begin{array}{l}\text { Education } \\
\text { Categories }\end{array}$} \\
\hline a. No schooling & 17789 & 12392 & 0.55 & 0.51 \\
\hline b. Primary school & 22082 & 14658 & 0.68 & 0.60 \\
\hline c. Junior high school & 27808 & 16341 & 0.85 & 0.67 \\
\hline d. Senior high school & 32621 & 24353 & 1.00 & 1.00 \\
\hline d. College & 39502 & 28179 & 1.21 & 1.16 \\
\hline f. University & 53198 & 38891 & 1.63 & 1.60 \\
\hline g. Graduate school & 104810 & 75852 & 3.21 & 3.11 \\
\hline
\end{tabular}

Notes: Education gaps are the proportions of mean wages of different education level groups to the mean wage of senior high school.

Data source: Calculated based on CGSS2005 and CGSS2013.

\section{Econometric Analysis Results}

\subsection{Results of Returns to Schooling}

Table 3 summarizes wage function results based on equation (1). The coefficient of years of schooling is estimated IRR. Estimation (1) uses the total sample (male + female), Estimation (2) uses subsamples: male or female. The main findings of Estimation (1) are as follows.

First, the coefficients of years of school are 0.086 (male 0.083, female 0.090) for 2005, and 0.078 (male 0.074 , female 0.082 ) for 2013. It is shown that from 2005 to 2013 , IRR decreased from $8.6 \%$ to $7.8 \%$ for the total sample, from $8.3 \%$ to $7.4 \%$ for men, from $9.0 \%$ to $8.2 \%$ for women. These results are similar to Heckman and Li (2004), Zhang et al. (2007), Giles, Park and Wang (2008), Chen and Hamori (2009), Ge and Yang (2011), Kang and Peng (2012), Liu and Zhang (2012), Ren and Miller (2012). As shown in Appendix Table 1, the IRR values in these studies are in the range from 1.4 (Byron and Manaloto, 1990) to 44.0 (Wang, 2012a) in urban China. The estimated IRR in the study are among the values in previous studies.

Second, the IRR decreases from 2005 to 2013 for both men and women. The results may be caused by the labor supply of high-level education workers increasing greatly with the implementation of the higher education expansion policy. In the other wards it is indicated that there may exist an over education problem for the high-level education group in China after the implementation of the higher education expansion policy.

Third, other factors also affect the wage level. Generally, (1) average wage is $22.1 \%$ (2005), $32.2 \%$ (2013) higher for men than that for women, a gender wage gap in both 2005 and 2013 is indicated, and the gender wage gap expanded 
from 2005 to 2013. These results are consistent with Gustafsson, and Li (2000), and Li and Ma (2015). (2) Wages are higher for the more experienced year group in 2013. (3) To compare with minority group, the wage is $15.8 \%$ higher for the Han majority group in 2005, whereas the Han majority dummy variable is not statistically significant in 2013. A wage gap occurs between minority and majority groups in 2005 , whereas the wage gap became smaller in 2013. (4) The wage is $39.2 \%$ (2005), $17.0 \%$ (2013) higher for a regular worker than for an irregular worker. Although there is a wage gap between the regular worker and the irregular worker groups in both 2005 and 2013, the wage gap became smaller from 2005 to 2013. This might be because the economic transition, the impact of market-mechanism on wage determination in the public sector became greater, thus the wage gap between the public sector and the private sector decreased. (5) The influence of marital status on wage is not statistically significant in 2005, whereas, in 2013, the coefficient of the married dummy variable is 0.157 for male, and -0.092 for female, and they are statistically significant at a 1 10\% level. It is indicated that the discrimination by maternal status for women increased from 2005 to 2013. (6) The wage gap between the various industrial sectors decreased from 2005 to 2013. (7) The wage gap between various occupational groups was smaller in both 2005 and 2013. (6) When the other factors are consistent, the average wage is higher for the private sector than for the public sector in both 2005 and 2013. (8) The wage is higher for urban residents than that for rural resident in 2005, while the wage gap is greater for rural resident than that for urban residents at a 10\% statistical level in 2013. It is shown that the wage gap by the registration system became smaller from 2005 to 2013. (9) There are regional wage gaps in both 2005 and 2013. To compare the economic developed region (Eastern Region), the wage is lower for the economic developing region (Central region and West region).

Lastly, Estimation (2) shows the IRR differs by gender, and the influences of individual characteristic and sector dummy variables on wage also differ by gender. We will discuss more details on gender disparity of IRR in the following (section 4.3).

Table 3. Results of wage function: Estimation (1)

\begin{tabular}{|c|c|c|c|c|c|c|}
\hline & \multicolumn{3}{|c|}{2005} & \multicolumn{3}{|c|}{2013} \\
\hline & \multirow{2}{*}{$\frac{\text { Estimation (1) }}{\text { Total }}$} & \multicolumn{2}{|c|}{ Estimation (2) } & \multirow{2}{*}{$\begin{array}{c}\text { Estimation (1) } \\
\text { Total }\end{array}$} & \multicolumn{2}{|c|}{ Estimation (2) } \\
\hline & & Male & Female & & Male & Female \\
\hline \multirow[t]{2}{*}{ Years of schooling } & $0.086^{* * *}$ & $0.083 * * *$ & $0.090 * * *$ & $0.078 * * *$ & $0.074 * * *$ & $0.082 * *$ \\
\hline & $(0.005)$ & $(0.007)$ & $(0.008)$ & $(0.005)$ & $(0.007)$ & $(0.008)$ \\
\hline \multirow[t]{2}{*}{ Exp. } & -0.000 & 0.003 & -0.003 & $0.033 * * *$ & $0.033 * * *$ & $0.025 * * *$ \\
\hline & $(0.005)$ & $(0.006)$ & $(0.008)$ & $(0.004)$ & $(0.006)$ & $(0.007)$ \\
\hline \multirow[t]{2}{*}{ Exp-sq. } & 0.000 & 0.000 & 0.000 & $-0.000 * * *$ & $-0.001 * * *$ & $-0.000 * *$ \\
\hline & $(0.000)$ & $(0.000)$ & $(0.000)$ & $(0.000)$ & $(0.000)$ & $(0.000)$ \\
\hline \multirow[t]{2}{*}{ Male } & $0.221 * * *$ & & & $0.322 * * *$ & & \\
\hline & $(0.026)$ & & & $(0.026)$ & & \\
\hline \multirow[t]{2}{*}{ Party } & -0.025 & -0.060 & 0.081 & -0.003 & -0.003 & -0.003 \\
\hline & $(0.038)$ & $(0.045)$ & $(0.075)$ & $(0.036)$ & $(0.046)$ & $(0.061)$ \\
\hline \multirow[t]{2}{*}{ Han } & $0.158 * * *$ & $0.257 * * *$ & 0.053 & 0.006 & -0.013 & 0.029 \\
\hline & $(0.058)$ & $(0.076)$ & $(0.092)$ & $(0.056)$ & $(0.073)$ & $(0.089)$ \\
\hline \multirow[t]{2}{*}{ Regular worker } & $0.392 * * *$ & $0.356 * * *$ & $0.436 * * *$ & $0.170 * *$ & 0.107 & $0.276^{* *}$ \\
\hline & $(0.034)$ & $(0.046)$ & $(0.052)$ & $(0.078)$ & $(0.010)$ & $(0.128)$ \\
\hline \multirow[t]{2}{*}{ The married } & 0.030 & 0.054 & -0.004 & 0.048 & $0.157 * * *$ & $-0.092 *$ \\
\hline & $(0.038)$ & $(0.051)$ & $(0.058)$ & $(0.034)$ & $(0.047)$ & $(0.051)$ \\
\hline \multicolumn{7}{|l|}{$\begin{array}{l}\text { Industry sectors } \\
\text { (The other) }\end{array}$} \\
\hline \multirow[t]{2}{*}{ Primary } & $-0.314 * * *$ & $-0.269 *$ & $-0.401 * *$ & 0.070 & 0.170 & -0.098 \\
\hline & $(0.115)$ & $(0.149)$ & $(0.182)$ & $(0.203)$ & $(0.248)$ & $(0.356)$ \\
\hline Secondary & $-0.090 *$ & -0.064 & $-0.141 *$ & 0.113 & $0.156^{*}$ & 0.030 \\
\hline
\end{tabular}




\begin{tabular}{|c|c|c|c|c|c|c|}
\hline & $(0.051)$ & $(0.064)$ & $(0.084)$ & $(0.069)$ & $(0.087)$ & $(0.117)$ \\
\hline Tertiary & $\begin{array}{l}-0.027 \\
(0.051)\end{array}$ & $\begin{array}{l}-0.014 \\
(0.064)\end{array}$ & $\begin{array}{l}-0.075 \\
(0.085)\end{array}$ & $\begin{array}{c}0.057 \\
(0.067)\end{array}$ & $\begin{array}{c}0.133 \\
(0.085)\end{array}$ & $\begin{array}{l}-0.076 \\
(0.114)\end{array}$ \\
\hline \multicolumn{7}{|l|}{$\begin{array}{l}\text { Occupations } \\
\text { (The others ) }\end{array}$} \\
\hline \multirow[t]{2}{*}{ Manager } & $0.311^{*}$ & $0.488 * *$ & -0.131 & 0.204 & $0.326^{*}$ & 0.055 \\
\hline & $(0.179)$ & $(0.210)$ & $(0.340)$ & $(0.144)$ & $(0.185)$ & $(0.235)$ \\
\hline \multirow[t]{2}{*}{ Technician } & 0.162 & 0.236 & -0.093 & 0.023 & 0.100 & -0.018 \\
\hline & $(0.163)$ & $(0.195)$ & $(0.292)$ & $(0.141)$ & $(0.182)$ & $(0.228)$ \\
\hline \multirow[t]{2}{*}{ Clerk } & 0.077 & 0.203 & -0.211 & 0.035 & 0.094 & -0.011 \\
\hline & $(0.160)$ & $(0.191)$ & $(0.290)$ & $(0.142)$ & $(0.184)$ & $(0.229)$ \\
\hline \multirow[t]{2}{*}{ Manual worker } & 0.096 & 0.255 & -0.272 & -0.163 & -0.066 & -0.236 \\
\hline & $(0.159)$ & $(0.190)$ & $(0.289)$ & $(0.140)$ & $(0.180)$ & $(0.229)$ \\
\hline \multicolumn{7}{|l|}{$\begin{array}{l}\text { Ownership } \\
\text { (Private sector) }\end{array}$} \\
\hline \multirow[t]{2}{*}{ Government } & -0.075 & -0.035 & -0.147 & $-0.120 * *$ & -0.113 & -0.097 \\
\hline & $(0.061)$ & $(0.073)$ & $(0.111)$ & $(0.058)$ & $(0.070)$ & $(0.109)$ \\
\hline \multirow[t]{2}{*}{ SOE } & $-0.075^{* * *}$ & $-0.091 * *$ & -0.069 & $-0.066^{* *}$ & -0.049 & $-0.084 *$ \\
\hline & $(0.028)$ & $(0.037)$ & $(0.044)$ & $(0.029)$ & $(0.038)$ & $(0.046)$ \\
\hline \multicolumn{7}{|l|}{$\begin{array}{l}\text { Registration } \\
\text { (Urban) }\end{array}$} \\
\hline \multirow[t]{2}{*}{ Rural } & $-0.094 * *$ & $-0.160 * * *$ & -0.008 & 0.038 & $0.075^{*}$ & -0.030 \\
\hline & $(0.040)$ & $(0.051)$ & $(0.066)$ & $(0.031)$ & $(0.040)$ & $(0.047)$ \\
\hline \multicolumn{7}{|l|}{ Regions (West) } \\
\hline \multirow[t]{2}{*}{ East } & $0.387 * * *$ & $0.399 * * *$ & $0.373 * * *$ & $0.308 * * *$ & $0.346 * * *$ & $0.261 * * *$ \\
\hline & $(0.034)$ & $(0.044)$ & $(0.055)$ & $(0.040)$ & $(0.053)$ & $(0.060)$ \\
\hline \multirow[t]{2}{*}{ Central } & $0.074^{*}$ & $0.092 *$ & 0.035 & $-0.101 * *$ & -0.054 & $-0.159 * *$ \\
\hline & $(0.039)$ & $(0.049)$ & $(0.063)$ & $(0.044)$ & $(0.059)$ & $(0.066)$ \\
\hline \multirow[t]{2}{*}{ constants } & $7.482 * * *$ & $7.480 * * *$ & $7.894 * * *$ & $8.316 * * *$ & $8.497 * * *$ & $8.530 * * *$ \\
\hline & $(0.181)$ & $(0.217)$ & $(0.323)$ & $(0.177)$ & $(0.233)$ & $(0.272)$ \\
\hline observations & 2618 & 1,497 & 1,121 & 2,403 & 1,437 & 966 \\
\hline R-squared & 0.309 & 0.292 & 0.324 & 0.335 & 0.286 & 0.355 \\
\hline
\end{tabular}

Note: 1. $* * *, * * *$ denote statistical significant in $10 \%, 5 \%, 1 \%$ level.

2. Values in brackets are estimated standard deviations.

Source: Calculated based on CGSS2005 and CGSS2013.

\subsection{Results of Returns to Schooling by Various Education Category Groups}

Analysis based on equation (2) is employed to investigate the wage gaps between the various education category groups. These results are summarized in Table 4. The main results are as follows.

First, when the other factors (e.g. individual characteristics, occupation, industry, and work place, regions) are consistent, wage gaps by education category groups in both 2005 and 2013 are found. For example, in 2005, compared with the no schooling group, the logarithm of wage is $44.2 \%$ higher for primary school, $51.5 \%$ higher for junior high school, $75.3 \%$ higher for senior high school, $106.4 \%$ higher for college, $136.7 \%$ higher for university, and $167.1 \%$ higher for graduate school. In 2013, the logarithm of wage level is $42.6 \%$ higher for senior high school, $62.0 \%$ higher for college, $87.1 \%$ higher for university, and $144.2 \%$ higher for graduate school.

Second, generally, wage gaps between the various education category groups decreased from 2005 to 2013 . For example, even though there was a wage gap between no schooling and primary school, and junior high school in 
2005, the wage gaps between these groups are not statistically significant in 2013. The results indicated that the wage gap between the various low-level education groups became smaller in 2013. The values of coefficients for senior high school, college, university and graduate school are smaller for 2013 than for 2005 . The results may be caused by the implementation of the higher education expansion policy since 1999. The labor supply of high-level education increased from 2005 to 2013, which cause to that the wage gaps between low-education group and high-education groups to decrease.

Lastly, the wage gap between the various education category groups is greater for women than for men in both 2005 and 2013. For example, excepting the college group in 2005, all the values of the education category dummy variables are greater for women than men in both 2005 and 2013. It is found that the intra-group wage gap differs by gender.

Table 4. Results of wage function: Estimation (2)

\begin{tabular}{|c|c|c|c|c|c|c|}
\hline & \multicolumn{3}{|c|}{2005} & \multicolumn{3}{|c|}{2013} \\
\hline & \multirow{2}{*}{$\begin{array}{l}\text { Estimation(1) } \\
\text { Total }\end{array}$} & \multicolumn{2}{|c|}{ Estimation(2) } & \multirow{2}{*}{$\begin{array}{l}\text { Estimation(1) } \\
\text { Total }\end{array}$} & \multicolumn{2}{|l|}{ Estimation(2) } \\
\hline & & Male & Female & & Male & Female \\
\hline \multicolumn{7}{|l|}{ Education category } \\
\hline \multicolumn{7}{|l|}{ (No schooling) } \\
\hline \multirow[t]{2}{*}{ Primary school } & $0.442 * * *$ & $0.414 * *$ & $0.432 * *$ & 0.0612 & -0.075 & 0.146 \\
\hline & $(0.124)$ & $(0.179)$ & $(0.176)$ & $(0.147)$ & $(0.229)$ & $(0.190)$ \\
\hline \multirow[t]{2}{*}{ Junior high school } & $0.515^{* * *}$ & $0.459 * * *$ & $0.544 * * *$ & 0.203 & 0.110 & 0.240 \\
\hline & $(0.118)$ & $(0.173)$ & $(0.163)$ & $(0.141)$ & $(0.221)$ & $(0.180)$ \\
\hline \multirow[t]{2}{*}{ Senior high school } & $0.753^{* * *}$ & $0.671 * * *$ & $0.820 * * *$ & $0.426^{* * *}$ & 0.272 & $0.547 * * *$ \\
\hline & $(0.119)$ & $(0.174)$ & $(0.164)$ & $(0.142)$ & $(0.221)$ & $(0.182)$ \\
\hline \multirow[t]{2}{*}{ College } & $1.064 * * *$ & $1.055^{* * *}$ & $1.040 * * *$ & $0.620 * * *$ & $0.476 * *$ & $0.706^{* * * *}$ \\
\hline & $(0.123)$ & $(0.179)$ & $(0.173)$ & $(0.144)$ & $(0.225)$ & $(0.186)$ \\
\hline \multirow[t]{2}{*}{ University } & $1.367 * * *$ & $1.209 * * *$ & $1.535^{* * *}$ & $0.871 * * *$ & $0.718 * * *$ & $0.993 * * *$ \\
\hline & $(0.128)$ & $(0.185)$ & $(0.180)$ & $(0.146)$ & $(0.226)$ & (0.189) \\
\hline \multirow[t]{2}{*}{ Graduate School } & $1.671 * * *$ & $1.652 * * *$ & $1.704 * * *$ & $1.442 * * *$ & $1.240 * * *$ & $1.625^{* * *}$ \\
\hline & $(0.207)$ & $(0.257)$ & $(0.404)$ & $(0.169)$ & $(0.252)$ & $(0.233)$ \\
\hline \multirow[t]{2}{*}{ Male } & $0.219^{* * * *}$ & & & $0.324^{* * *}$ & & \\
\hline & $(0.0258)$ & & & $(0.0261)$ & & \\
\hline \multirow[t]{2}{*}{ constants } & $7.652 * * *$ & $7.642 * * *$ & $8.075^{* * *}$ & $8.763 * * *$ & $9.009^{* * *}$ & $8.955 * * *$ \\
\hline & $(0.206)$ & $(0.265)$ & $(0.345)$ & $(0.215)$ & $(0.308)$ & $(0.306)$ \\
\hline Observations & 2,618 & 1,497 & 1,121 & 2,403 & 1,437 & 966 \\
\hline R-squared & 0.322 & 0.306 & 0.345 & 0.351 & 0.302 & 0.378 \\
\hline
\end{tabular}

Note: $1 . * * *, * * *$ denote statistical significant in $10 \%, 5 \%, 1 \%$ level.

2. Values in brackets estimated standard deviation.

Data source: Calculated based on CGSS2005 and CGSS2013.

The IRR for the various education category groups is calculated based on equation (3), the results are summarized in Table 5. The main findings are as follows.

First, to consider the IRR for the high-level education groups, (1) the IRR of university (15.35\%) is higher than for 
the other education category groups in 2005. The IRR of graduate school $(19.03 \%)$ is higher than for the other education groups in 2013. These results are consistent with human capital theory, the higher the education level the higher the wage. (2) The IRR of university decreased from $15.35 \%$ in 2005 to $11.15 \%$ in 2013 . The results might be because the labor supply of university graduates increased with the implementation of higher education expansion policy. Although it is thought the increase of high-level education workers may be due to the decrease of IRR for the high-level education group, when the labor demand for high-level education workers increased along with the explosion of technological innovation, the wage for the high-level education group may increase, which may cause the rise of the IRR for the high-level education group. The results in the study indicate that the influence of the labor supply side factor on the university group wage is greater than labor demand side factor. (3) However, the IRR of graduate school rose from $10.1 \%$ (2005) to $19.0 \%$ (2013). It is indicated that the higher education expansion policy positively affects the wage for the highest level education group.

Second, to compare the return to schooling between the low, middle and high-level education groups, in 2005, the IRR is higher for the low-level and high-level education groups, and lower for the middle-level education group: these results are similar to Lou's (2009). However, in 2013, to compare with low-level education group, the IRR are higher for middle-level and high-level education groups. These results may be because after the world financial crisis in 2007-2008 the Chinese government implemented the industry upgrade policy to change industry from a low-technological level to higher level; and the technology innovations increased with economic growth. Thus the labor demand might have become greater for the middle-level education group (e.g. the junior and senior high school) than that for low-level education group in 2013.

Lastly, the IRR differs by gender for each educational category group, but the situations differ by period. For example, to look at the high-level education groups, (1) the IRR of graduate school is higher for men (14.8\%) than for women (5.6\%) in 2005; whereas it is higher for women (21.1\%) than for men (17.4\%) in 2013. It is clear that the increase of IRR of graduate school is greater for women than men. (2) Even though the IRR of university is higher for women (17.9\%) than men (13.5\%) in 2005, the IRR is the similar for women and men, both of them are $11.2 \%$ in 2013.

Table 5. Results of return to schooling by various education category groups

\begin{tabular}{|c|c|c|c|c|c|c|}
\hline & \multicolumn{3}{|c|}{2005} & \multicolumn{3}{|c|}{2013} \\
\hline & Total & Male & Female & Total & Male & Female \\
\hline a. Primary school & 0.074 & 0.069 & 0.072 & 0.010 & -0.013 & 0.024 \\
\hline b. Junior high school & 0.024 & 0.015 & 0.037 & 0.047 & 0.063 & 0.031 \\
\hline c. Senior high school & 0.079 & 0.071 & 0.092 & 0.074 & 0.054 & 0.102 \\
\hline d. College & 0.104 & 0.128 & 0.073 & 0.065 & 0.068 & 0.053 \\
\hline e. University & 0.154 & 0.135 & 0.179 & 0.111 & 0.112 & 0.112 \\
\hline f. Graduate school & 0.101 & 0.148 & 0.056 & 0.190 & 0.174 & 0.211 \\
\hline
\end{tabular}

Date source: Calculated based on the estimated results shown in Table 5.

\subsection{Robustness Checks: Estimation of IRR by Groups}

\section{(1) IRR by gender}

Table 6 summarizes the results of IRR by gender. Estimation (1) uses male and female groups separately based on equation (1). Estimation (2) uses the total samples including both male and female groups based on equation (4). The interaction of male dummy variable and school year is utilized in Estimation (2) which shows the gender disparity of IRR based on the assumption that the other factors (e.g. human capital) are similar. The main findings are as follows.

First, the results in Estimation (1) show the IRR is higher for women (9.0\% in 2005, $8.3 \%$ in 2013) than for men (8.9\% in2005, 7.4\% in 2013) in both 2005 and 2013. These results are consistent with previous studies (Li and Ding, 2003; Chen and Ju, 2004; Zhang, et al., 2005; and Ma, 2011) (Note 13).

Second, the results in Estimation (2) show that when other factors are consistent, the IRR is $1.8 \%$ (2005), $1.6 \%$ (2013) lower for men than that for women.

Both Estimation (1) and Estimation (2) indicate a gender disparity of IRR: the IRR is greater for women than men in both 2005 and 2013. 
Table 6. Results of gender disparity of IRR

\begin{tabular}{|c|c|c|}
\hline & 2005 & 2013 \\
\hline \multicolumn{3}{|l|}{$\begin{array}{l}\text { Estimation (1): Schooling } \\
\text { years }\end{array}$} \\
\hline \multirow[t]{2}{*}{ Male } & $0.083 * * *$ & $0.074 * * *$ \\
\hline & $(0.007)$ & $(0.007)$ \\
\hline \multirow[t]{2}{*}{ Female } & $0.090 * * *$ & $0.083 * * *$ \\
\hline & $(0.008)$ & $(0.008)$ \\
\hline \multicolumn{3}{|l|}{ Estimation (2) } \\
\hline \multirow[t]{2}{*}{ Schooling years } & $0.096 * * *$ & $0.087 * * *$ \\
\hline & $(0.007)$ & $(0.007)$ \\
\hline \multirow[t]{2}{*}{ Male } & $0.428^{* * *}$ & $0.521^{* * *}$ \\
\hline & $(0.098)$ & $(0.097)$ \\
\hline \multirow[t]{2}{*}{ Male $\times$ Schooling years } & $-0.018^{* *}$ & $-0.016^{* *}$ \\
\hline & $(0.008)$ & $(0.008)$ \\
\hline
\end{tabular}

Note: $1 . *, * *, * * *$ denote statistical significant in $10 \%, 5 \%, 1 \%$ level.

2. Values in brackets estimated standard deviation.

3. Experience years, male, party member, the married, Han, regular worker, occupation (Manager, Technician, Clerk, Manual), industry (Primary, Secondary, Service industries), work place sector (government organization, SOEs), registration (the rural), regions (Eastern, Central Regions) dummy variables are also estimated, these results are not shown in Table 5.

Data source: Calculated based on CGSS2005 and CGSS2013.

Why is the return to education greater for women than men in China? There are three reasons.

First, based on Becker (1957), when the employer, colleague, or customer prefer a male to a female worker, even though the years of school are similar, the wage may differ by gender, which causes the gender disparity of IRR (discrimination hypothesis). Discrimination against female workers is widespread, and the gender wage gap expanded during the economic transition period in China (Gustafsson and Li, 2000; Maurer-Fazio and Hughes, 2002; Xing, et al., 2014; Zhao, 2014; and Li and Ma, 2015).

Second, Zhang, et al. (2005) suggest it may be caused by self-selection. Based on the home productivity model, Becker (1985) pointed out that because men can earn a higher wage in the market than women, and women take more responsibility for child care and parent care than men, labor participation is lower for women than men. The scarcity of female workers based on self-selection may cause the IRR to be greater for women than for men (the self-selection hypothesis).

Third, when the proportion of high-level education workers are less in the female group than for the male group, a high-level education female labor supply shortage may occur, therefore to compare with the low-level education group, the probability of the high-level education group getting better jobs is greater for women than men, which may cause the IRR to be greater for women than men. In China, particularly in the rural region, because of the influence of Confucianism, boys might receive more preferential treatment than girls, therefore the boy might enjoy more intra-household resources (Liu, 2008). When the investment in education in a household is higher for a boy than for a girl, there will be fewer female workers with a high-level education entering the labor supply. The scarcity of female higher-level education workers may be because of the gender disparity of IRR (scarcity of female higher-level education worker hypothesis). The IRR values may be explained as follows. When the influence is greater for the self-selection hypothesis and the scarcity of female worker hypothesis than for the discrimination hypothesis, the IRR will be greater for women than for men. 


\section{(2) IRR by ownership types, registration systems, industry and region category groups}

To consider the samples heterogeneities by ownership types, registration systems, industrial groups and regional groups, the IRR are calculated for each group, and the results are summarized in Table 7. Estimation (1) analyses the total sample. Estimation (2), (3), (4), and (5) are analysed using subsamples separately, public sector and private sector in Estimation (2); urban resident group and rural resident group in Estimation (3); manufacturing industry and service industry in Estimation (4); and Western, Central and Eastern Regions in Estimation (5). The main results are as follows.

First, the IRR for government organizations is greater $(9.5 \%$ in $2005,9.7 \%$ in 2013$)$ than for state-owned enterprises (SOEs) and the private sector in both 2005 and 2013; in 2005, IRR of SOEs (8.2\%) is smaller than for the private sector $(8.5 \%)$, whereas in 2013, the IRR for SOEs $(8.5 \%)$ is greater than private sector $(7.2 \%)$; the IRR for the public sector (government organization, and SOEs) rose from 2005 to 2013, whereas the IRR for the private sector decreased in the period (Estimation 2). These may be because the progress of SOEs reform, and the influence of market mechanisms on wages became greater in the public sector from 2005 to 2013.

Second, the IRR of urban residents $(8.8 \%$ in $2005,9.5 \%$ in 2013) is greater than that for rural residents $(6.8 \%$ in 2005, 5.4\% in 2013) in both 2005 and 2013; the IRR of urban residents increased from 2005 to 2013, whereas the IRR of rural residents decreased in the period (Estimation 3). It is indicated the problem of segmentation by registration system may have become more serious from 2005 to 2013.

Third, in 2005 the IRR is smaller for secondary industry (7.8\%) than tertiary industry (8.6\%), whereas in 2013 the IRR is greater for secondary industry $(8.2 \%)$ than for tertiary industry (7.3\%). The IRR increased from 2005 to 2013 for secondary industry, whereas the IRR decreased for tertiary industry in the period (Estimation 4). This may be because the proportion of irregular workers is greater for the tertiary industry sector than for the secondary industry sector. More empirical studies of the wage gap between regular workers and irregular workers in China are needed.

Fourth, to compare the Eastern Region and the Western Region, the IRR of the Central Region is lowest in both 2005 and 2013 (6.7\% in 2005, $3.5 \%$ in 2013). Moreover, the IRR of the Eastern Region increased from 9.1\% to 9.7\%, whereas the IRR of the Central Region decreased from 6.7\% to 3.5\%, and the IRR of the Western Region decreased from $9.2 \%$ in 2005 to $5.5 \%$ in 2013 . The results can be explained by the fact that the economic development level is highest in the Eastern Region, and the labor demand for the high-level education group is higher for the Eastern Region.

These results indicated that generally, IRR values differ between various groups, and the changes of IRR from 2005 to 2013 also differ by various groups. To look at the results for women and men separately, the disparity of IRR by various groups are similar with the results utilized the total samples. The IRR for all groups is greater for women than for men in both 2005 and 2013. The results confirm the gender disparity of IRR in China when considering the heterogeneities by groups.

Table 7. Results of IRR by ownership types, registration systems, industry and region groups

\begin{tabular}{|c|c|c|c|c|c|c|}
\hline & \multicolumn{2}{|c|}{2005} & \multicolumn{4}{|c|}{2013} \\
\hline & Total & Male & Female & Total & Male & Female \\
\hline \multicolumn{7}{|c|}{ Estimation (1): } \\
\hline \multirow[t]{2}{*}{ Total } & $0.086^{* * * *}$ & $0.083 * * *$ & $0.090 * * *$ & $0.078 * * *$ & $0.074 * * *$ & $0.083^{* * * *}$ \\
\hline & $(0.005)$ & $(0.007)$ & $(0.008)$ & $(0.005)$ & $(0.007)$ & $(0.008)$ \\
\hline \multicolumn{7}{|c|}{$\begin{array}{l}\text { Estimation (2): } \\
\text { Ownership types }\end{array}$} \\
\hline \multirow[t]{2}{*}{ Government } & $0.095 * * *$ & $0.124 * * *$ & 0.042 & $0.097 * * *$ & $0.109 * * *$ & $0.113 * *$ \\
\hline & $(0.029)$ & $(0.035)$ & $(0.072)$ & $(0.018)$ & $(0.021)$ & $(0.042)$ \\
\hline \multirow[t]{2}{*}{ SOEs } & $0.082 * * *$ & $0.076^{* * *}$ & $0.091 * * *$ & $0.085 * * *$ & $0.080^{* * * *}$ & $0.089^{* * * *}$ \\
\hline & $(0.008)$ & $(0.009)$ & $(0.013)$ & (0.009) & $(0.011)$ & $(0.014)$ \\
\hline \multirow[t]{2}{*}{ Private } & $0.085 * * *$ & $0.082 * * *$ & $0.091 * * *$ & $0.075^{* * *}$ & $0.072 * * *$ & $0.078^{* * * *}$ \\
\hline & $(0.007)$ & $(0.010)$ & $(0.011)$ & $(0.006)$ & $(0.009)$ & $(0.010)$ \\
\hline
\end{tabular}

Estimation (3): 


\begin{tabular}{|c|c|c|c|c|c|c|}
\hline \multicolumn{7}{|l|}{$\begin{array}{l}\text { Registration } \\
\text { groups }\end{array}$} \\
\hline \multirow[t]{2}{*}{ Rural } & $0.068 * * *$ & $0.071 * * *$ & $0.054 * * *$ & $0.057 * * *$ & $0.054 * * *$ & $0.060 * * *$ \\
\hline & $(0.013)$ & $(0.017)$ & $(0.020)$ & $(0.008)$ & $(0.012)$ & $(0.012)$ \\
\hline \multirow[t]{2}{*}{ Urban } & $0.088 * * *$ & $0.084 * * *$ & $0.095^{* * *}$ & $0.096^{* * *}$ & $0.089 * * *$ & $0.103^{* * *}$ \\
\hline & $(0.006)$ & $(0.007)$ & $(0.009)$ & $(0.006)$ & $(0.008)$ & $(0.010)$ \\
\hline \multirow{2}{*}{\multicolumn{7}{|c|}{$\begin{array}{l}\text { Estimation (4): } \\
\text { Industry groups }\end{array}$}} \\
\hline & & & & & & \\
\hline \multirow[t]{2}{*}{ Secondary } & $0.078 * * *$ & $0.086 * * *$ & $0.073 * * *$ & $0.087 * * *$ & $0.082 * * *$ & $0.088 * * *$ \\
\hline & $(0.009)$ & $(0.011)$ & $(0.015)$ & $(0.008)$ & $(0.010)$ & $(0.015)$ \\
\hline \multirow[t]{2}{*}{ Tertiary } & $0.086 * * *$ & $0.073 * * *$ & $0.073 * * *$ & $0.075 * * *$ & $0.073 * * *$ & $0.080 * * *$ \\
\hline & $(0.007)$ & $(0.009)$ & $(0.015)$ & $(0.007)$ & $(0.009)$ & $(0.009)$ \\
\hline \multirow{2}{*}{\multicolumn{7}{|c|}{$\begin{array}{l}\text { Estimation (5): } \\
\text { Region groups }\end{array}$}} \\
\hline & & & & & & \\
\hline \multirow[t]{2}{*}{ East } & $0.091 * * *$ & $0.092 * * *$ & $0.092 * * *$ & $0.097 * * *$ & $0.092 * * *$ & $0.103 * * *$ \\
\hline & $(0.007)$ & $(0.009)$ & $(0.011)$ & $(0.006)$ & $(0.008)$ & $(0.010)$ \\
\hline \multirow[t]{2}{*}{ Central } & $0.067 * * *$ & $0.065 * * *$ & $0.071 * * *$ & $0.035 * * *$ & $0.029 * *$ & $0.046 * * *$ \\
\hline & $(0.011)$ & $(0.014)$ & $(0.018)$ & $(0.010)$ & $(0.013)$ & $(0.018)$ \\
\hline \multirow[t]{2}{*}{ West } & $0.092 * * *$ & $0.079 * * *$ & $0.112 * * *$ & $0.055 * * *$ & $0.057 * * *$ & $0.062 * * *$ \\
\hline & $(0.012)$ & $(0.016)$ & $(0.019)$ & $(0.014)$ & $(0.021)$ & $(0.020)$ \\
\hline
\end{tabular}

Note: $1 . * * *, * * *$ denote statistical significant in $10 \%, 5 \%, 1 \%$ level.

2. Values in brackets estimated standard deviation.

3. The other variables-experience years, male, communist party member, regular worker, the married, race, rural registration, industry sector, occupation, ownership, and region dummy variable are estimated, the results are not expressed in Table 8.

Data source: Calculated based on CGSS2005 and 2013.

\section{Conclusions}

Using the Chinese General Social Survey data conducted in 2006 and 2014 (CGSS2005, CGSS2013), this study takes an empirical study to estimate the private internal rate of return to years of schooling (IRR) in the 2000s. The major conclusions are as follows.

First, overall, from 2005 to 2013 , the IRR decreased from $8.6 \%$ to $7.8 \%$ for the total sample, from $8.3 \%$ to $7.4 \%$ for men, and from $9.0 \%$ to $8.2 \%$ for women.

Second, to compare the IRR for the various education category groups, in 2005 the IRR are higher for low-level and high-level education groups, and lower for the middle-level education groups. In 2013, the IRR are higher for the middle-level and the high-level education groups than for the low-level education groups. The IRR of the high-level education group is higher than the low, middle and high-level education groups in both 2005 and 2013.

Third, to consider the impact of the higher education expansion policy implemented since 1999 on IRR, for the high-level education group: (1) in 2005 the IRR at university level is higher for the high-level education group than the other education category groups, and in 2013 the IRR at graduate school level is the highest of all education category groups. (2) The IRR at university level decreased from $15.4 \%$ in 2005 to $11.2 \%$ in 2013, whereas the IRR at graduate school level increased from $10.1 \%$ in 2005 to $19.0 \%$ in 2013 . The policy negatively affected the IRR at university level, but positively affected the IRR at graduate school level.

Fourth, the results using subsamples of men and women show that the IRR is higher for women than men in both 2005 and 2013. The results using interaction of a gender dummy variable and school year indicate that when the other factors are consistent, the IRR is $1.8 \%$ lower for men in 2005 and $1.6 \%$ lower for men in 2013 . These results denote a gender disparity of IRR in both 2005 and 2013. 
Lastly, the IRR values differ by ownership types, registration systems, industrial and regional groups.

The policy implications of the study can be considered as follows. First, it is indicated that the IRR decreased for the university group, whereas the IRR increased for the graduate school group from 2005 to 2013. It is thought that after the higher education extension policy was implemented the labor supply of university graduates increased dramatically. This may have contributed to the problem of over-education for university graduates which may have contributed to the decrease of IRR at university level. However, the higher education extension policy may promote technological innovation and raise the IRR of graduate school graduates. More strict analysis needs to be done to evaluate the effect of the higher education extension policy on the labor market (e.g. higher-level education worker labor supply and demand, wage gap between high-level education group and middle-level, low-level education group) (Note 14) in the future. Second, the IRR is higher for women than men when the factors which affect wage level are controlled. It has been suggested that supporting more girls to receive high-level education may reduce the gender wage gap (Dougherty, 2005; Liu, 2008; and Ma, 2011). Indeed, the admission rate to middle-level and high-level education is lower for girls than for boys in rural regions. In order to build an equal society, the education policy may be amended by the government to increase public education investment in rural regions and to reduce the gender education gap.

\section{Acknowledgments}

This research was supported by JSPS KAKENHI Grand Number JP16K03611, and Research Promotion Project of Institute of Economic Research, Hitotsubashi University. We are very grateful to professor Ichiro Iwasaki (Hitotsubashi University), professor Kazuhiro Kumo (Hitotsubashi University), and Dr. Richard Lingwood for their helpful comments and suggestions.

\section{References}

Asadullah, M. N. (2006). Returns to education in Bangladesh. Education Economics, 14(4), 453-468.

Beaudry, P., \& Lewis, E. (2012). Do male-female wage differentials reflect differences in the return to skill? Cross-city evidence from 1980-2000. American Economic Journal: Applied Economics, 6(2), 178-194.

Becker, G. S. (1957). The Economics of Discrimination. Chicago: University of Chicago Press.

Becker, G. S. (1964). Human Capital: A Theoretical and Empirical Analysis, with Special Reference to Education. New York: Columbia University Press.

Becker, G. S. (1985). Human capital, effort, and the sexual division of labor. Journal of Labor Economics, 3(1), 33-58. Retrieved from http://www.jstor.org/stable/2534997

Bishop, J. A., \& Chiou, J. R. (2004). Economic transformation and earnings inequality in China and Taiwan. Journal of Asian Economics, 15(3), 549-562. https://doi.org/10.1016/j.asieco.2004.05.009

Byron, R., \& Manaloto, E. (1990). Returns to education in China. Economic Development and Cultural Change, 38(4), 783-796.

Chang, J., \& Xiang, J. (2013). Higher education expansion and returns to college education. Chinese Journal of Population Science, 3, 104-111. (in Chinese)

Chang, J., \& Zhao, H. (2016). The impact of work unit's ownership on wage differentials between the labor of urban and rural household registration. Chinese Economic Quarterly, 15(2), 627-646. (in Chinese)

Chen, G., \& Hamori, S. (2009). Economic returns to schooling in urban China: OLS and instrumental variables approach. China Economic Review, 20(2), 143-152. https://doi.org/10.1016/j.chieco.2009.01.003

Chen, G., Demurger, S., \& Fournier, M. (2005). Wage differentials and ownership structure of China's enterprises. World Economic Paper, 6, 11-31. (in Chinese)

Chen, L., \& Ju, G. (2004). An empirical study on the gender differentials of return to schooling by Mincer model. Peking University Education Review, 2(3), 40-45. (in Chinese)

Demurger, S., Li, S., \& Yang, J. (2012). Earning differentials between the public and private sectors in China: exploring changes for urban local residents in the 2002s. China Economic Review, 23, 138-153.

Deng, F., \& Ding, X. (2012). Human capital, labor market segmentation and gender income gap. Sociological Studies, 5, 24-46. (in Chinese) 
Dougherty, C. (2005). Why are the returns to schooling higher for women than for men? Journal of Human Resources, 40(4), 969-988. Retrieved from http://www.jstor.org/stable/4129547

Fang, H., Eggleston, K., Rizzo, J., Rozelle, S., \& Zeckhauser, R. J. (2012). The Returns to schooling: evidence from the 1986 compulsory education law. NBER Working Paper, No. 18189.

Fleisher, B., Li, H., Li, S., \& Wang, X. (2004). Sorting, selection and transformation of return to college education in China. IZA Discussion Paper, No. 1446.

Gao, W., \& Smyth, R. (2015). Education expansion and returns to schooling in urban China, 2001-2010: evidence from three waves of the China urban labor survey. Journal of the Asia Pacific Economy, 20(2), 178-201. http://dx.doi.org/10.1080/13547860.2014.970607

Ge, S., \& Yang, D. T. (2011). Labor market developments in China: a neoclassical view. China Economic Review, 22(4), 611-625. https://doi.org/10.1016/j.chieco.2011.07.003

Giles, J., Park, A., \& Wang, M. (2008). The great proletarian cultural revolution, disruptions to education and returns to schooling in urban China. World Bank Policy Research Working Paper, No. 4729.

Gustafsson, B., \& Li, S. (2000). Economic transformation and the gender earnings gap in urban China. Journal of Population Economics, 13(2), 305-329. https://doi.org/10.1007/s001480050140

He, Y. (2009). The changes of rate of return to education: An empirical study based on CHNS. Chinese Journal of Population Science, 2, 44-54. (in Chinese)

Heckman, J., \& Li, X. (2004). Selection bias, comparative advantage, heterogeneous returns to education: evidence from China in 2000. Pacific Economic Review, 9(3), 155-171. https://doi.org/10.1111/j.1468-0106.2004.00242.x

Johnson, E. N., \& Chow, G. (1997). Rates of return to schooling in China. Pacific Economic Review, 2(2), 101-113. https://doi.org/10.1111/1468-0106.t01-1-00026

Kang, L., \& Peng, F. (2012). Siblings, public facilities and education returns in China. MPRA Paper, No. 38922.

Kimenyi, M. S., Mwabu, G., \& Manda, D. K. (2006). Human capital externalities and private returns to education in Kenya, Eastern Economic Journal, 32(3), 493-513.

Lai, D. (1998). Education, labor market, and income distribution. Economic Research Journal, 5, 42-49. (in Chinese)

Li, F., Morgan, W. J., \& Ding, X. (2008). The expansion of higher education, employment and over-education in China. International Journal of Educational Development, 28(6), 687-697. https://doi.org/10.1016/j.ijedudev.2007.10.002

Li, H. (2003). Economic reform and returns to education in China. Economics of Education Review, 22(3), 317-328. (in Chinese)

Li, H., \& Luo, Y. (2004). Reporting errors, ability heterogeneity and returns to schooling in China. Pacific Economic Review, 9(3), 191-207. https://doi.org/10.1111/j.1468-0106.2004.00244.x

Li, S., \& Ding, S. (2003). Long-term change in private returns to education in urban China. Social Sciences in China, 6, 58-72. (in Chinese)

Li, S., \& Ma, X. (2015). Impact of minimum wage on gender wage gaps in urban China. IZA Journal of Labor and development, 4, 20. https://doi.org/10.1186/s40175-015-0044-4

Liu, Z. (1998). Earnings, education and economic reforms in urban China. Economic Development and Cultural Change, 46(4), 697-725.

Liu, Z. (2008). Why are returns to education higher for the women than for men: an analysis based on gender wage discrimination. Economic Science, 2, 119-128. (in Chinese)

Ma, X. (2011). Female Labour Participation in China: Transformation of the Urban Labour Market in the Marketization Process. Tokyo: Keio University Press. (in Japanese)

Ma, X. (2015). Economic transition and wage differentials between public and private sectors in China. China-USA Business Review, 14(10), 477-494. https://doi.org/10.17265/1537-1514/2015.10.001

Ma, X. (2016a). Determinants of the wage gap between migrants and local urban residents in China: 2002-2013. Modern Economy, 7, 786-798. http://dx.doi.org/10.4236/me.2016.77081 
Ma, X. (2016b). Changes of wage structures in Chinese public and private sectors: 1995-2007. Management Studies, 4(6), 1-13. https://doi.org/10.17265/2328-2185/2016.06.002

$\mathrm{Ma}, \mathrm{X}$. (2016c). Impacts of minimum wage policy on wage distributions in urban China: comparison between public and private sectors. Chinese Studies, 5, 45-61. http://dx.doi.org/10.4236/chnstd.2016.53006

Maurer-Fazio, M., \& Hughes, J. (2002). The effects of market liberalization on the relative earning of Chinese women. Journal of Comparative Economics, 30, 709-731.

Messinis, G. (2013). Returns to education and urban-migrant wage differentials in China: IV quantile treatment effects. China Economic Review, 26, 39-55. https://doi.org/10.1016/j.chieco.2013.03.006

Mincer, J. (1974). Schooling, Experience and Earning. New York: Columbia University Press.

Mishra, V., \& Smyth, R. (2013). Economic returns to schooling for China's Korean minority. Journal of Asian Economics, 24, 89-102. https://doi.org/10.1016/j.asieco.2012.09.001

Mishra, V., \& Smyth, R. (2014). Returns to schooling in China's urban labour market: evidence from matched employer-employee data for Shanghai. In Cheng, Z., Wang, M., \& Chen, J. (Eds.), Chinese Cities in the New Era: Market Reform, Current State, and the Road Forward (pp. 169-183). Berlin: Springer.

National Bureau of Statistics. (2016). China Statistical Yearbook-2016. Beijing: China Science Press. (in Chinese)

Nozaki, Y. (2006). Decomposition of gender wage gap: analysis based on education background. The Japan Society of Household Economics, 22, 151-166. (in Japanese)

Psacharopoulos, G. (1981). Return to education: an updated international comparison. Comparative Education, 17(3), 321-341.

Psacharopoulos, G., \& Patrinos, H.A. (2004). Returns to investment in education: a further update. Education Economics, 12(2), 111-134.

Qian, X., \& Smyth, R. (2008). Measuring regional inequality of education in China: widening coast-inland gap or widening rural-urban gap? Journal of International Development, 20(2), 132-144. https://doi.org/10.1002/jid.1396

Qiu, T., \& Hudson, J. (2010). Private returns to education in urban China. Economic Change and Restructuring, 43(2), 131-150. https://doi.org/10.1007/s10644-009-9081-9

Ren, W., \& Miller, P. (2012). Changes over time in the return to education in urban China: conventional and ORU estimates. China Economic Review, 23(1), 154-169. https://doi.org/10.1016/j.chieco.2011.08.008

Sano, S., \& Yasui, K. (2009). Estimating the return to education in Japan: evidence from repeated cross-sectional data. National Economic Journal, 200(5), 71-86. (in Japanese)

Sun, Z. (2004). Individual returns to education in China: literatures and policy implications. Chinese Journal of PopulationScience, 5, 65-80. (in Chinese)

Trostel, P., Walker, I. \& Woolley, P. (2002). Estimates of the economic return to schooling for 28 countries. Labour Economics, 9(1), 1-16. https://doi.org/10.1016/S0927-5371(01)00052-5

Wang, L. (2012a). Economic transition and college premium in urban China, China Economic Review, 23(2), 238-252. https://doi.org/10.1016/j.chieco.2011.11.001

Wang, L. (2012b). Social exclusion and education inequality: towards an integrated analytical framework for the urban-rural divide in China. British Journal of Sociology of Education, 33(3), 409-430. http://dx.doi.org/10.1080/01425692.2012.659455

Wang, L. (2013). How does education affect the earnings distribution in urban China? Oxford Bulletin of Economics and Statistics, 75(3), 435-454. https://doi.org/10.1111/j.1468-0084.2012.00697.x

Wang, X., \& Liu, J. (2011). China's higher education expansion and the task of economic revitalization. Higher Education, 62(2), 213-229. (in Chinese)

Wu, Y., \& Zhao, Q. (2010). Higher education expansion and employment of university graduates. Economic Research Journal, 9, 93-108. (in Chinese)

Xing, C., \& Li, S. (2011). Higher education expansion, education opportunity and unemployment of college graduates. The China Economic Quarterly, 10(4), 1187-1208. (in Chinese) 
Xing, C., Jia, S., \& Li, S. (2013). Regional distribution of the return to education for rural-to-urban migrants and its impact on migration. Economic Research Journal, 11, 114-126. (in Chinese)

Xing, C., Jia, S., \& Li, S. (2014). Technical change, return to education, and gender wage differentials in urban China. Studies in Labor Economics, 3, 42-62. (in Chinese)

Yang, P. (2012). Education, industry segregation and gender wage gap: evidence from college graduates surveys in China. Peking University Education Review, 10(3), 95-113. (in Chinese)

Ye, L., Li, S., \& Luo, C. (2011). Industrial monopoly, ownership and enterprises wage inequality: An empirical research based on the first national economic census of enterprises data. Management World, 4, 26-36. (in Chinese)

Zhang, J., \& Xue, X. (2008). State and non-state sector wage differentials and human capital contribution. Economic Research, 4, 15-25. (in Chinese)

Zhang, J., Liu, P. W., \& Yung, L. (2007). The Cultural Revolution and returns to schooling in China: estimates based on twins. Journal of Development Economics, 84 (2), 631-639. https://doi.org/10.1016/j.jdeveco.2006.12.006

Zhang, J., Zhao, Y., Park, A., \& Song, X. (2005). Economic returns to schooling in urban China, 1988 to 2001. Journal of Comparative Economics, 33(4), 730-752. https://doi.org/10.1016/j.jce.2005.05.008

Zhang, L., Li, S., Darity, J. W. A., \& Sharpe, R. V. (2014). Wage discrimination by registration in the Chinese labor market. Management World, 11, 35-46. (in Chinese)

Zhang, Z., \& Chen, Q. (2013). College expansion and gender equalization in higher education: an empirical study based on the 2008 general social survey. Sociological Studies, 2, 173-196. (in Chinese)

Zhao, X. (2014). Measurement and decomposition of gender discrimination in China's urban labor market. Management Review, 7, 62-71. (in Chinese)

Appendix 1. Summary of Previous Studies on the Return to Education in China

\begin{tabular}{lllll}
\hline Previous Studies & $\begin{array}{l}\text { Analysis } \\
\text { objects }\end{array}$ & Published year & Model & Estimated IRR (\%) \\
\hline Byron and Manaloto (1990) & Urban China & 1986 & OLS & 1.4 \\
\hline Johnson and Chow (1997) & Urban China & 1988 & OLS & 3.3 \\
\hline Liu (1998) & Urban China & 1988 & OLS & $2.9-3.6$ \\
\hline Lai (1998) & Urban China & 1995 & OLS & $5.14-5.99$ \\
\hline Li (2003) & Urban China & 1995 & OLS & $4.7-5.4$ \\
\hline Li and Deng (2003) & Urban China & $1990-1999$ & OLS & $1.19-4.75$ \\
\hline Bishop and Chiou (2004) & Urban China & 1988,1995 & OLS & $2.8,5.6$ \\
\hline Fleisher et al. (2004) & Urban China & $1988-2002$ & IV & $16.9-38.6$ \\
\hline Heckman and Li (2004) & & & OLS & \\
\hline
\end{tabular}

$\begin{array}{llll}\text { Zhang, et. al (2005) } \quad \text { Urban China } & 1988-2001 & \text { OLS } & \text { M:2.9-8.4 } \\ & & \text { OLS } & \text { F:5.2-13.2 }\end{array}$

\begin{tabular}{lllll}
\hline Zhang, et al. (2007 & Urban China & 2002 & Twins & $3.8-9.8$ \\
\hline Giles, et al.(2008) & Urban China & 2000 & IV & $8.3-9.6$ \\
\hline
\end{tabular}




\begin{tabular}{|c|c|c|c|c|}
\hline Qian and Smyth (2008) & Urban China & 2005 & OLS & $12.0-13.0$ \\
\hline Liu (2008) & Urban China & 2004 & OLS & $5.43-10.93$ \\
\hline \multirow{2}{*}{ Chen and Hamori (2009) } & \multirow{2}{*}{ Urban China } & \multirow{2}{*}{2004,2006} & OLS & OLS:7.7-8.1 \\
\hline & & & IV & IV:12.6-14.5 \\
\hline Qiu and Hudson (2010) & Urban China & $\begin{array}{l}1989,1993, \\
1997,2000\end{array}$ & OLS & $5.1-6.9$ \\
\hline \multirow{3}{*}{ Ma (2011) } & \multirow{3}{*}{ Urban China } & \multirow{3}{*}{$1988-2002$} & \multirow{3}{*}{ OLS } & Total: $3.24-11.07$ \\
\hline & & & & M:2.45-9.21 \\
\hline & & & & $F: 3.34-12.09$ \\
\hline Ge and Yang (2011) & Urban China & $1988-2011$ & OLS & $3.6-11.4$ \\
\hline \multirow{2}{*}{ Kang and Peng (2012) } & \multirow{2}{*}{ Urban China } & \multirow{2}{*}{ 1989-2009 } & OLS & OLS:2.2-10.3 \\
\hline & & & IV & IV:6.2-11.0 \\
\hline Ren and Miller (2012) & Urban China & 2004,2006 & OLS & $7.0-8.0$ \\
\hline Fang, et al. (2012) & Urban China & $1997-2006$ & IV & 20.0 \\
\hline Mishra and Smyth (2013) & $\begin{array}{l}\text { Ethnic Koreans } \\
\text { in urban China }\end{array}$ & $2009-2010$ & IV & $21.0-23.0$ \\
\hline Wang (2012a) & Urban China & 1995,2002 & IV & $9.5-44.0$ \\
\hline \multirow{2}{*}{ Wang (2013) } & \multirow{2}{*}{ Urban China } & \multirow{2}{*}{1995,2002} & OLS & OLS:3.6-8.1 \\
\hline & & & IV & IV:4.4-11.8 \\
\hline Deng and Ding (2013) & Chin & 2010 & OLS & $9.3-11.7$ \\
\hline Mishra and Smyth (2014) & Shanghai & 2007 & OLS & $6.9-7.4$ \\
\hline \multirow{5}{*}{ Chen and Ju (2004) } & \multirow{5}{*}{ Urban China } & 1996 & OLS & $\mathrm{M}: 4.7, \mathrm{~F}: 6.5$ \\
\hline & & 1997 & OLS & M:5.0, F: 9.1 \\
\hline & & 1998 & OLS & M:6.1, F:9.8 \\
\hline & & 1999 & OLS & M:4.9, F: 8.2 \\
\hline & & 2000 & OLS & M:6.7, F:10.3 \\
\hline \multirow{6}{*}{ Gao and Smyth (2015) } & \multirow{6}{*}{ Urban China } & \multirow{6}{*}{$\begin{array}{l}2001,2005, \\
2010\end{array}$} & OLS & 2001:6.78 \\
\hline & & & OLS & $2005: 7.81$ \\
\hline & & & OLS & 2010:8.60 \\
\hline & & & IV & $2001: 8.24$ \\
\hline & & & IV & $2005: 8.72$ \\
\hline & & & IV & 2010:9.00 \\
\hline
\end{tabular}

Notes: 1. OLS: ordinary least square analysi010s

IV: instrument variable estimation method

2. M: Male; F: Female

Source: Sun (2004), Gao and Smyth (2015), Table 1 and authors. 


\section{Notes}

Note 1. In previous studies, the period from 1949 to 1977 is usually named as the "planned economy period", while the period after 1978 until now is usually referred to as the "economic transition period".

Note 2. Based on NBS data (NBS, 2016), the urban registered unemployment rate increased from 3.0\% in 1996 to $4.3 \%$ in 2001 . It should be noted that the actual unemployment rate was higher than the unemployment rate published by government.

Note 3. For the issue on the returns to schooling in the other countries, please see Beaudry and Lewis (2012) for the U.S., Nozaki (2006), Sano and Yasui (2009) for Japan, Asadullah (2006) for Bangladesh, Kimenyi, et al. (2006) for Kenya. For the detail of survey on IRR in China, please refer to Sun (2004), and Gao and Smyth (2015).

Note 4. For the wage gap between rural resident and urban resident groups, please refer to Wang (2012b), Messinis (2013); Zhang, et al. (2014), and Chang and Zhao (2016); for the regional wage gaps, please see Qian and Smyth (2008), Xing, et al. (2013), Ma (2016a); for the wage gap between various industry sectors, please refer to Yang (2012).

Note 5. For the wage structure and wage gap between public and private sectors, please refer to Lai (1998), Chen, et. al. (2005), Zhang and Xue (2008), Ye, et al. (2011), Demurger, et al. (2012), and Ma (2015, 2016b, 2016c)

Note 6. In order to address the heterogeneity problem, the IV (instrument variable) method is also used in the previous studies (Fleisher et al., 2004; Chen and Hamori, 2009; Fang et al., 2012; Kang and Peng, 2012; Fang, 2012; Mishra and Smyth, 2013; Wang, 2012, 2013; Gao and Smyth, 2015), Chen and Feng (2011), and Kang and Peng (2012). It may be argued that because the instrument variables (e.g., spouse's education, and parent's education) may be in correlation with the family background and they may indirectly affect both education attainment and wage, therefore these instrument variables may be not exogenous. It is known that when the IV is not exogenous, a greater bias may occur in the estimation utilized IV than in the estimated results based on OLS. Because this study focus on IRR by periods and various groups, OLS which is usually used in the previous study is used in the study.

Note 7. The sampling stages for CGSS2005 are as follows: (1) A total of 125 primary sampling units (PSU) are selected for the national sample. (2) Four secondary sampling units (SSU) are selected in each selected PSU. (3) Two third-level sampling units (TSU) are selected in each selected SSU. (4) Ten households are selected in each selected TSU. One eligible person older than 18 (18-69 for 2003) is randomly selected from each sampled household to serve as respondent. PSUs are county-level units. There are 2801 PSUs.

The sampling stages for CGSS2013 are as follows: (1) PSUs are county-level units, there are 2,762 PSUs in the sampling frame. (2) SSUs are community-level units (villages and neighborhood committees). (3) In selected SSU, 25 households (TSUs) are sampled with the PPS method. (4) In each selected household, an 18 and above adult will be sampled with a Kish grid. There are 43 municipalities directly under the central government, provincial capital cities, and vice provincial cities in China. Comprehensive ranking by GDP, FDI and Education Level to these cities, the top 5 are Beijing, Shanghai, Tianjin, Guangzhou, and Shenzhen. The CGSS2013 design set these 5 cities as a self-representative stratum. This stratum consists of 67 PSUs. The rest 2,695 PSUs are comprehensively ranked with GDP per capital, urbanization rate, and population density and then are equally classified into 50 strata.

Note 8 . Based on the retirement system and employee basic pension system implemented in public sector, retired age is 50 or 55 for women, 60 for men in China.

Note 9. Although considering the influence of work hours on wage, the hourly wage should be utilized in wage function, we cannot gain information about work hours from CGSS. Therefore the annual wages are used in the study.

Note 10. In China, the year of schooling is 15 for college, 16 for university.

Note 11. Experience years = age $-6-$ years of education

Note 12. Private-owned enterprise includes foreign-investment enterprise, collectively owned enterprise, and private enterprise.

Note 13. In addition, Dougherty (2005), Psacharopoulos and Patrinos (2004), Trostel, et al. (2002) pointed out that the IRR is greater for women than men in the developed countries.

Note 14. For the impact of higher-education expansion policy on employment, please refer to Wu and Zhao (2010), Xing and Li (2011); for the impact of higher-education expansion policy on gender wage gap, please refer to $\mathrm{He}$ (2009), Gao and Smyth (2015). 